\title{
LESBIAN DESIRE AND MAINSTREAM MEDIA: SARAH WATERS'S TIPPING THE VELVET ON THE SCREEN ${ }^{1}$
}

\author{
Lea Heiberg Madsen, University of Malaga \\ Email: 1.madsen@uma.es
}

\begin{abstract}
The subversive potential and transformative strength of the neo-Victorian genre is explored and consolidated by writers such as Sarah Waters. In her debut novel Tipping the Velvet (1998) the author makes explicit what was virtually impossible to express in Victorian times, but also what is still struggling for socio-cultural recognition. However, can the TV adaptation of Waters's lesbian Bildungsroman be said to achieve the same? This article explores the adaptation of the novel, broadcast on British television in 2002, and discusses whether or not its re-presentation of female same-sex erotics discredits the issue of lesbianism.

Keywords: Sarah Waters, neo-Victorian, female same-sex erotics, Tipping the Velvet on the screen.
\end{abstract}

Título en español: El deseo lésbico y la política de los medios: la adaptación televisiva de Tipping the Velvet de Sarah Waters

Resumen: Gracias a Sarah Waters, entre otras, la crítica especializada ha reconocido la capacidad subversiva y transformadora del fenómeno conocido como Neo-Victorianism. En la novela Tipping the Velvet (1998) la autora hace explícito lo que era imposible expresar en la época victoriana, pero también lo que todavía no ha encontrado total reconocimiento desde el punto de vista social y culturalmente. Sin embargo, ¿se puede afirmar que la adaptación televisiva de la novela resulta asimismo subversiva? Este artículo analiza la adaptación emitida en la televisión británica en 2002 y cuestiona si la representación del erotismo lésbico subraya la normalización de la figura lesbiana.

Palabras claves: Sarah Waters, novela neo-Victoriana, Tipping the Velvet, erotismo, lesbianismo, adaptación televisiva.

Ever since the rise of the neo-Victorian novel, there has been a constant and significant increase in publications of and on neo-Victorian fiction, testifying to its popularity with the public as well as with scholars. The particularly high production of neo-Victorian feminist novels is a clear sign of the genre's suitability for the feminist discourse which, as Gayle Greene observes, is concerned with escaping repetition and ensuring progress (1991: 291). ${ }^{2}$

Date of reception: 27 May 2010

Date of acceptance: 18 July 2010

2 Among many others, Sarah Waters's Tipping the Velvet (1998); Affinity (1999); Fingersmith (2002); Michel Faber's The Crimson Petal and the White (2002); Barbara Chase-Riboud's Hottentot Venus (2004); Belinda Starling's The Journal of Dora Damage (2006). 
Critics have argued that "[n]eo-Victorian novelists take their cues from a second wave of predominantly female and, in part, feminist researchers, who reclaimed female subjectivity from the hitherto predominantly male definition" (Voigts-Virchow 2009: 110). Most, however, also recognize the neo-Victorian genre as a "hybrid space" (borrowing VoigtsVirchow's expression) where it is possible to argue "against long-established clichés" (Llewellyn 2009: 28), and to address issues that remain highly relevant at present. NeoVictorian re-workings, thus, often imply a revision of now as much as of then.

Sarah Waters debuted in 1998 with Tipping the Velvet, for which she has won great academic and popular recognition, and with which she successfully, and in a very overt manner, introduced 'the lesbian' into mainstream popular culture. What is commonly known as her neo-Victorian trilogy -which, apart from Tipping the Velvet, includes Affinity (1999) and Fingersmith (2002)- has marked not only the author's breakthrough as a writer of fiction but, arguably, the very realm of neo-Victorian literature. Her debut novel, nevertheless, remains the most path-breaking of the three in its explicit representation of women's same-sex erotics. That is, in Tipping the Velvet Waters leaves little to read between the lines when it comes to same-sex passion and sexual dynamics. Subtlety is, in other words, substituted with explicit eroticism and sex. As M.-L. Kohlke remarks: "Waters breathes life into Terry Castle's notion of the 'Apparitional Lesbian,' giving her flesh, blood, sex, and cunt...[t]here is nothing remotely spectral or unreal about lesbian sex here..." (2006: 9). Thus, the female characters in Tipping the Velvet live out their erotic passions-aloud.

As many critics observe, Waters's neo-Victorian lesbian Bildungsroman works on various levels. Tipping the Velvet is an example of how the neo-Victorian "mode" (borrowing Mark Llewellyn's expression) offers multilayered readings and may reveal as much about the author's present as about the re-imagined past. Waters, in effect, is not merely revising the past. As a neo-Victorian writer she engages in revision through re-presentation. She, accordingly, digs out the hidden and buried, fills in the gaps, and lends her voice to the silenced Victorians. Her voicing of the unspoken, however, is double-edged. As Llewellyn argues, she criticises "[Victorian] modes of dealing with social and sexual transgression, but also the late twentieth and early twenty-first-centuries' responses to similarly perceived deviance" (2004: 213). Waters's re-workings of issues surrounding female same-sex erotics, thus, is a re-evaluation of the position of the lesbian of both then and now; or, as Paulina Palmer suggests, a renegotiation of the lesbian's “abject role" (2007: 49). In other words, Waters challenges both past and persisting perceptions of female (homo) sexuality.

Tipping the Velvet has already been much celebrated for its transgressive and subversive qualities-and Sarah Waters, for the conviction and strength with which she has put both her lesbian narrative and herself, as a minority writer, on the map of mainstream culture. However, Waters comes to fill a gap in manifold ways. Tipping the Velvet, as some suggest, is not literally a re-presentation nor is Waters a re-producer, since the Victorian lesbians were never represented in the first place. She is not "re-writing", Eckart Voigts-Virchow remarks, "[b]ecause there is no Victorian novel on lesbian subculture" (2009: 120). At the same time, Tipping the Velvet marks a turning point for the lesbian discourse in mainstream culture at present, where it remains marginalised and, as critics argue, "lesbian fiction is literary monstrosity" (Llewellyn 2004: 213). Waters, however, escapes this persisting marginalisation. As a writer she both represents and re-presents the position of the lesbian 
in popular culture, receiving academic and popular recognition on par with any other mainstream novelist or, perhaps, to an even greater extent. However, not only has she successfully ensured herself a place on the map as a lesbian writer, but also as one of the most widely read neo-Victorian authors.

The subversive potential and transformative strength of the neo-Victorian genre is both explored and consolidated by writers such as Sarah Waters. With Tipping the Velvet (and her subsequent neo-Victorian novels) she makes explicit what was virtually impossible to express in Victorian times, but also what is still struggling for socio-cultural recognition. However, can the TV adaptation of her novel be said to achieve the same? In what follows, I explore Andrew Davies's adaptation of Tipping the Velvet, broadcast as a three-part series on British television in 2002, and discuss whether or not - as some critics suggest - "there is something strange going on in the presentation of the lesbian desire" (MacPherson 2008: 270). As point of departure for my discussion, I analyse the re-presentation of female same-sex erotics in a number of scenes, comparing the adaptation with the original. First, however, I provide a brief introduction to period drama on screen, focusing on its recent developments as a parallel to the trends of neo-Victorian literature.

Fiction set in the nineteenth-century, whether we think of novels, short stories, or films, is obviously nothing new. As one critic points out: "[t]he nineteenth-century novel has been a staple of twentieth-century entertainment...[and] both American and British audiences have an insatiable hunger for films with historical settings and films based on great books" (Troost 2007: 75). However, historical series in the 1990s, as others observe, were likely to be regarded a manifestation of cultural heritage rather than as portraying the female experience:

The gender-blindness of the dominant British critical approach to heritage cinema is sufficiently strange as to seem almost wilful, given the historical associations of femininity with a (culturally constructed) disposition towards the pleasures of the (popular and literary) novel, the costume film, female-centred narratives and 'female' genres such as romance and melodrama; and, last but not least, the pleasures of consumption. (Monk qtd. in Kleinecke 2006: 160)

In recent years, however, the genre of period drama has indeed opened up for representations of alternative experiences, giving room for those of the marginalised and the minorities. Kleinecke suggests that there has been a "move away from patriarchal versions of grand History toward histories that are lived and experienced...towards the discovery of alternative truths, which very often focuses on female subjectivities" (2006: 160). This is a tendency that manifests itself in films, television series and, not least, in literature.

One of the first definitions of the neo-Victorian novel, provided by Dana Shiller in 1997, stresses how this sub-type of the historical novel "plays on (and with) our certainties about history...explores the ground between writing as though there are no persisting truths...and writing as though there is indeed a recoverable past" (1997: 540-541). The neo-Victorians go back to nineteenth-century England to revise, re-evaluate and revitalize the Victorians, seeking, however, not so much to reproduce the great Victorian culture as to establish a form of dialogue with it. The neo-Victorian text, thus, goes beyond its historical setting and 
plots. It deconstructs and subverts the Victorian novel, explores and re-works the nineteenth century's preoccupations with, for example, race, gender and sexuality while, simultaneously, working as an approach to our own age's anxieties.

Just like the neo-Victorian novel provides a space for challenging dominant cultural norms of both past and present, the adaptation of literature onto television may also open up for ways to subvert and transgress boundaries. In fact, Troost's definition of "Heritagestyle adaptations", as "British television serials that pride themselves on their historical authenticity...display English heritage...[while]...simultaneously criti[cising] it" (2007: 82), echoes, to a certain extent, the neo-Victorian revisionist approach to Victorian culture and history. So, a TV format may offer - as does the neo-Victorian novel - a kind of "third space" (borrowing Voigts-Virchow's expression) where dialogues between past and present can develop. As another critic, moreover, observes: "[t]elevision productions are a good source of space for challenging pre-conceived notions of normality, and a closed reading of the text in television format allows the 'reality' to become the 'truth"' (MacPherson 2008: 265). Television and (neo-Victorian) literature, then, are both potentially transformative sites. This does not mean, though, that the two together double their potential. Indeed, TV "has a potential for intimacy that arises from its domestic setting and its consequent role within our everyday lives" (Cardwell 2007: 186), but it is also a highly conventional format. In effect, the adaptation of such an unconventional and subversive text as Tipping the Velvet onto a $\mathrm{BBC}$ prime-time series has proven to be a challenge which, according to some critics, has been solved far from satisfactorily. The adaptation has been much criticised for taking shortcuts in its re-presentation of lesbian sex, and some claim that Tipping the Velvet on screen appears as a farce, and is turned into a mere spectacle for the viewer. Among others, Pauline MacPherson maintains that the series is a "production that brings the female back under the control of the male gaze" (2008: 274).

In a recent article, MacPherson explores how "adaptations of literature to film can be read in order to understand the changing reality of female sexuality" (2008: 261), and how, in the last few years, there has been a rise in adaptations of popular literature dealing with controversial and challenging issues such as female sexuality and lesbianism. She discusses the representation of lesbian identities on British television, "from Oranges to Velvet", without hiding her profound dislike for Andrew Davies's re-workings of Waters's novel. MacPherson views Tipping the Velvet on screen as almost opposed to the novel which displays a "motivation to act for changes in society, or as a re-think of people's perceptions about homosexuality" (2008: 263). She points out the all-male production crew and post-modernist influences as crucial factors for the adaptation's failure "in terms of functioning as a subversive format" (MacPherson 2008: 271), and finds that it merely "distorts and turns the lesbian love scenes into a comedic show" (MacPherson 2008: 270). Jenni Millbank reaches a similar conclusion and remarks: "[i]t is, perhaps, still impossible for lesbian desire to be received by mainstream media in any other way, as they after all, are playing to their audience, whose heterosexuality requires reassurance of both its naturalness and dominance in the face of such rupture" (2004: 181). I believe, nevertheless, that a more open reading than such is possible. That is, I do not regard the speeding up of the action, unrealistic time frames, and its comic elements a clear expression of the adaptation's "question[ing] the legitimacy of lesbian desire" (MacPherson 2008: 271). Nor do I find 
that lesbianism is reduced to farce. In fact, I think the TV production in many ways reveals the director's preoccupation with re-transmitting the 'spirit' of Sarah Waters's novel. As Cardwell explains, 'fidelity' remains important in today's television and film adaptations of classic novels and contemporary literature. However, whereas it previously implied being faithful to the words of the novel, nowadays "fidelity has been reconfigured and adaptors have become more concerned with conveying the 'spirit' of the source text...the affiliation to the source text remains, but it is possibly better conceptualized as a desire to show respect to that text, rather than to be faithful to it" (Cardwell 2007: 193, original emphases).

Tipping the Velvet tells the story about Nance Astley who goes from being a young, innocent oyster girl in Whitstable (England), to becoming a successful music-hall performer, social-rights public speaker and confident lesbian woman in London. As the narrator of her own story, Nan reflects upon her experience and personal development in and through her erotic relationships with a number of different women-relationships which involve betrayal, abuse and severe emotional scars, but also tender love-making, and steamy hot sex. It is through her encounter with the male-impersonator Kitty Butler that Nan first experiences an erotic awakening and initiates her psycho-emotional journey, exploring and gradually discovering her (sexual) identity.

The very first time Nan and Kitty make love is a key moment in the novel. Nan's narration of the experience has a poetic beauty to it while, simultaneously, it is loaded with sensuality and crude eroticism. Waters depicts the two women who finally give in to their sexual desire in highly emotional terms. Indeed, the scene is very moving - anyone who has ever been in love cannot but relate to Nan's paradoxical feelings of bubbling pleasure and aching pain - but it is also extremely erotic. In the rather long passage (Tipping the Velvet 98-105) which builds up to the actual love-making scene, Waters offers minute detail of Nan and Kitty's preliminary touching and kissing, leaving little to read between the lines. Their foreplay is very passionate, their desire very sexual. Thus, Waters is not merely hinting at the women's passion for each other, but seeks, rather, to let it materialize. In effect, she thoroughly avoids lesbian spectralization, symbolic female bonding, and offers instead a straight-forward portrayal of female same-sex desire. In other words, Waters not only makes it 'real', she also takes it to its climax-with moans, groans and orgasms. In the TV adaptation, the scene remains very passionate and intimate (minute 45:45 and onwards, episode 1). Moreover, as a central moment in the story of Nan Astley, the adaptation's concern with the original details seems particularly high. This is reflected, for instance, in its exact reproduction of the dialogue between the lovers: "'May I really — touch you?' I whispered. She gave again a nervous laugh, and tiltede her face against her pillow. 'Oh Nan,' she said, 'I think I shall die if you don't!'” (Waters 1998: 105). Short after, the camera similarly captures the detail of how “[Kitty's] own hands began to chafe distractedly at the flesh of my shoulders" (Waters 1998: 105). So, the filmic version arguably remains faithful to novel's depiction of the love scene.

It has been argued, though, that in the subsequent depictions of the sexual relations between Kitty and Nan, "the camera is used to present the action as speeded up...and to focus upon comedy" (MacPherson 2008: 210). Some claim that, with his adaptation of Tipping the Velvet, Andrew Davies merely creates a 'spectacle'-undoing, in a sense, what Waters achieved in the first place with her novel. As previously mentioned, MacPherson 
perceives "its predominantly male production team and the influences of postmodernism" (2008: 271) as complicating factors for the retransmission of its original subversive quality. There may, nevertheless, be many reasons why the adaptation, generally, goes for a more rapid and non-explicit re-presentation of Nan's sexual encounters.

Davies, as I suggest above, is successful in his re-transmission of Nan and Kitty's first night as lovers. Notwithstanding a few changes in the dialogues and a slight speeding-up of the events, the adaptation indeed conveys the emotions involved and the highly erotic atmosphere of the moment in line with the novel. By re-producing, in large, Waters's depiction - respecting the centrality of the scene as well as its explicit erotic expression - Tipping the Velvet on screen arguably re-presents the lovers' first time as close to the original representation as possible (for a production aimed at a prime-time audience). This, consequently, makes it unnecessary to display in detail the many subsequent sexual encounters between Nan and Kitty. I am thereby not saying that the detailed descriptions of lesbian sex in the novel are irrelevant. The graphic sex and, not least, the very varied depictions of female same-sex erotics in Tipping the Velvet, contribute to the unique quality of Waters's work. However, as the adaptation makes sure that we get the picture the first time, it hereafter remains clear what goes on in their bedroom at night. In other words, we know that they have hot, passionate sex, without it being explicitly shown over and over again. So, in contrast to MacPherson who maintains that "Tipping the Velvet [is] transformed into a male voyeristic lesbian fantasy" (2008: 272), I find that the adaptation rather avoids such transformation. That is, would it not be precisely an invitation to voyeurism if passages such as the following were explicitly shown on TV?:

Here she was wet, and smooth as velvet. I had never, of course, touched anyone like this before - except sometimes myself; but is was as if I touched myself now, for the slippery hand which stroked her seem to stroke me: I felt my drawers grow damp and warm...I ceased my gentle strokings and began to rub her, rather hard...between her legs, with one wet fingertip. (Waters 1998: 105)

One of the last erotic scenes in the novel portrays Nan and Flo-and though it is the last, it is far from being the least explicit:

...and after a moment I felt her move within me, first with one finger, then with two, I guessed, then three...At last, after a second's pressure, she had her hand in me up to the wrist. I think I called out - I think I shivered and panted and called out, to feel the subtle twisting of her fist, the curling and uncurling of her sweet fingers, beneath my womb.... (Waters 1998: 428)

The women's love-making, nevertheless, conveys much more than simply good sex. Nan's orgasm works as a symbol for her having reached a certain climax in her development. She is now an experienced, self-confident lover and partner of Florence Banner. On screen, the scene is re-presented in terms of a fading image of the women cuddling and kissing. Again, as in the case with Kitty and Nan, the lack of explicit visualization of their love-making does not disturb me. Non-explicit, here, is not equal to invisible or superficial. Nan and Flo are there, their passion is there, and their erotic desire is materialized-it 
simply cannot be gazed at. The adaptation, then, moves on and focuses on other aspects of Nan's growth which, as clearly perceived in the novel, are as significant for her story. In effect, the adaptation remains a TV version of Waters's lesbian Bildungsroman and avoids transforming it into a show.

What MacPherson repeatedly criticizes is the speeding up of and use of comedy in the adaptation's portrayal of lesbianism. However, I do not recognize the "farcical performance" (MacPherson 2008: 271) she sees. In fact, one of the most comic moments in the entire adaptation involves heterosexual sex, namely, the scenes in which Nan prostitutes herself in the disguise of a girlish soldier (minute 11:52 and onwards, episode 2). Here, in my opinion, the novel's female/lesbian perspective indeed comes to expression: on the one hand, by ridiculing the men Nan prostitutes herself to; on the other, by depicting her as emotionally detached and not the least sexually aroused by the male sex. In line with the novel, the adaptation captures how:

[a]s they strained and gasped, and whispered their desires to me in some alley or court or dripping lavatory stall - I would have to turn my face away to hide my smiles...well, they were all gents and (whatever their own opinion on the matter) with their trousers unbuttoned they all looked the same. I never felt my own lust rise, raising theirs. (Waters 1998: 206)

Although the adaptation, to a large extent, omits the more gloomy sides of Nan's experience on the streets, it successfully re-transmits the concept of performativity involved in her occupation as a renter. With a series of rapid shots of Nan in different costumes, and with lively, circus-like music to accompany her 'show,' the TV production, like the novel, foregrounds the irony in Nan's sad situation. However, what the adaptation does fail to reproduce is Waters's double-edged use of comedy here. In the novel, the depiction of Nan as a renter in terms of comic performance can be read as ironic in itself-as an expression of the protagonist's self-deceit. Nan's show is, in other words, ambiguous: she is performing not only for the sake of fooling the men she is with, but also herself. Behind the secret smiles and fancy costumes she hides, in fact, her desperation and self-loath.

From this point and onwards, the adaptation lets Nan's narration continue in a comic mode. This strategy, however, is not too farfetched since Nan, at this point, is still running her show. To escape reality, as I argue above, Nan herself perceives life as a theatre with her as the main actor. This, in effect, gives Davies the opportunity to go on playing with the theatrical and farcical in the scenes that follow. It is, thus, through the use of comic elements that Davies chooses to re-present Nan's first sexual encounter with Diana Lethaby, one of the most erotically loaded and sexually explicit scenes in the novel. However, the 'spirit' of the original (borrowing Cardwell's expression) is definitely there. The scene builds up to the sexual climax with a teasing slowness, and where the adaptation differs or is less explicit in erotic detail it reproduces the exact words of the original dialogue: "If you were the King of Pleasure,' she said, 'and I were Queen of Pain...' Then in a different tone: 'You're very handsome Miss King'” (Waters 1998: 239). As in the novel, Diana remains semi-dressed during the sexual act. The adaptation, however, covers up much more than the women's naked skin. There is, in other words, no "catching hold on her nipples...hard fingering" or 
sign of how "the dildo that serviced her also pleasured me" (Waters 1998: 243). The scene is accompanied by symphonic music playing louder and louder, as if trying to drown the "breaths [that] became moans, then cries" (Waters 1998: 243) which, consequently, remain vague sighs in the adaptation. Not only does it result in a much softer, almost implicit, erotic encounter, the TV production practically erases the whole particularity of womanto-woman sex. Nan and Diana, in this sense, become standardized; what in the novel is so strictly lesbian about their sex is merely present through the fact that the lovers are women. Indeed. At one point, Nan and Diana could even be mistaken for a heterosexual couple, their love-making differing little (or none) from a conventional sex scene in a conventional, prime-time movie.

According to MacPherson, "the convention and the use of comedy destabilises the seriousness of female sexualities in this television production" (2008: 274). I agree that conventions take too much over and that the TV production consequently fails to celebrate lesbianism on par with the novel. However, I do not think that the adaptation opposes the intentions of the original, nor do I consider its comic approach particularly destabilising. As I have previously argued, comedy can be read in several ways, and its central role in the TV series does not consequently discredit the issue of lesbianism. In fact, Waters herself frequently turns to comedy to tell her story and Tipping the Velvet has often received the label 'romp.' Moreover, as Jayne Caudwell similarly argues, it is necessary to consider the gaze of the lesbian, who "[as] spectatrix experiences a diversity of pleasure and displeasure" (2004: 237), before dismissing the adaptation's portrayal of lesbianism as a failure. In her research into how lesbians perceived Tipping the Velvet on screen, Caudwell finds that "[i]f we accept poststructuralist notions of power then we can focus on the polysemic...begin to explore multiple meanings and therefore provide an understanding of the lesbian gaze" (2004: 235).

Sarah Waters's vivid depictions of lesbian erotics are too explicit for a prime-time television broadcast-not because she represents women's same-sex desires, but because her portrayal involves steamy hot, graphic sex. Whereas some critics see Davies's adaptation as a "production that finds itself easily incorporated into the male heterosexual voyeurism in which, as a novel, Tipping the Velvet does not participate" (MacPherson 2008: 274), I find, as previously said, that it rather escapes it. By toning down its display of lesbian sex, the adaptation comes to depict female homosexuality in a much broader sense than merely its erotics. Davies, obviously, turns Waters's novel into a prime-time, TV version. However, his 'standardization' of lesbian eroticism on the screen, needs neither to be perceived as a reappropriation of female sexuality nor as an expression of disrespect or lack of seriousness. It is true that Davies's adaptation tones down and largely erases the particularity of lesbianism in the sex scenes. This way of standardizing sex between women, nevertheless, can be read as a representation of 'lesbian' as a normalized sexuality. By fitting it into a conventional TV format, the screening of Tipping the Velvet, thus, becomes an act of subversion.

So, an open reading of Davies's adaptation instead of a closed - or as Millbank suggests, by avoiding "reductive readings of cultural texts as if they contained and passed on simple 'messages' about sex and sexuality" (2004: 157) - allows us to discover in it a tribute to Waters and her efforts to re-present a literary and cultural minority. It celebrates her story, her characters and, to a certain extent, succeeds in re-transmitting the intentions behind 
the novel. Andrew Davies introduces lesbianism, as identity and normalized sexuality, into prime-time television and, thus, into the mainstream of popular culture-something Sarah Waters did four years earlier with her novel.

To conclude, both as novel and in TV format, Tipping the Velvet works to challenge dominant socio-cultural perceptions of female identity and sexuality. However, literary and audiovisual productions obviously draw on different strategies of expression and representation. Whereas the novel depicts lesbianism through explicit eroticism and graphic sex the adaptation down-tones the sexual. Although Waters's approach to the issue of female homosexuality appears both refreshingly innovative and highly boundary-breaking, Davies's production proves that on TV, sometimes, less is more. By focusing on lesbian identity as much as on 'the lesbian' as sexuality, the adaptation captures lesbianism in a broader sense and not merely for the sake of eroticism. Davies successfully brings Waters's lesbian Bildungsroman into the living rooms of thousands of British families, and foregrounds - in line with the novel -several different aspects of the story about Nan Astley whose transformation is much more than a sexual one. As Waters brilliantly portrays in her novel, Nan develops into an independent, politically involved, young woman and selfconfident lesbian. The adaptation is open for a similar reading: Nan's sexuality is part of her identity, but it is not all she is.

\section{REFERENCES}

Cardwell, S. 2007. "Literature on the Small Screen: Television Adaptations". The Cambridge Companion to Literature on Screen. Eds. D. CARTMELl and I. Whelehan. Cambridge: Cambridge UP. 181- 195.

Caudwell, J. 2004. "Tipping the Velvet: Straight[Forward] Voyeurism? Problematising the Viewing of Lesbianism". Leisure, Media, and Visual Culture: Representations and Contestations. Eds. E. Kennedy and A. Thornton. Eastbourne: LSA Publications. 227-249.

Chase-Riboud, B. 2004. Hottentot Venus. New York: Anchor Books.

FABer, M. 2002. The Crimson Petal and the White. Orlando: Harvest and Harcourt.

Greene, G. 1991. "Feminist Fiction and the Uses of Memory". Signs 16, 2: 290-321.

KleineCKe, I. 2006. "Representations of the Victorian Age: Interior Spaces and the Detail of Domestic Life in Two Adaptations of Galsworthy's The Forsyte Saga". Screen 47, 2: 139-162.

Kohlke, M.-L. 2006. "The Neo-Victorian Sexation: Literary Excursions into the Nineteenth Century Erotic". Inter-Disciplinary.Net eBook of Proceedings of the 3rd Global Conference on Sex and Sexuality: Exploring Critical Issues. Krakow, 29 November - 2 December 2006. Malaga. $15^{\text {th }}$ Jan. 2009. http://www.inter-disciplinary. net/ci/sexuality/s3/Kohlke\%20paper.pdf

Llewellyn, M. 2004. “Queer? I should say it is criminal': Sarah Waters' Affinity (1999)". Journal of Gender Studies 13, 3: 203-214. 
. 2009. "Neo-Victorianism: On the Ethics and Aesthetics of Appropriation". LIT: Literature, Interpretation, Theory 20, 1-2: 27-45.

Macpherson, P. 2008. “'Fictions can Change. It's Only the Facts that Trap Us': Images of Female Sexuality from Oranges to Velvet". Women: A Cultural Review 19, 3: 261-274.

Millbank, J. 2004. "It's about this: Lesbians, Prisons, Desire". Social Legal Studies, 13, 2: 115-190.

PALMER, P. 2007. "Introduction: The Lesbian, the Abject, and Anglo-American Fiction". The Abject of Desire: The Aestheticization of the Unaesthetic in Contemporary Literature and Culture. Eds. K. KutzBach and M. Mueller. Amsterdam and New York: Rodopi. 49-67.

Shiller, D. 1997. "The Redemptive Past in the Neo-Victorian Novel". Studies in the Novel 29, 4: 538-560.

Starling, B. 2008. The Journal of Dora Damage. London: Bloomsbury.

Troost, L. V. 2007. “The Nineteenth-Century Novel on Film: Jane Austen”. The Cambridge Companion to Literature on Screen. Eds. D. Cartmell and I. Whelehan. Cambridge: Cambridge UP. 75-89.

VoIgTs-VIRCHOw, E. 2009. "In-yer-Victorian-face: A Subcultural Hermeneutics of NeoVictorianism". LIT: Literature Interpretation Theory 20, 1-2: 108-123.

Waters, S. 1998. Tipping the Velvet. London: Virago. 1999. Affinity. London: Virago. .2002. Fingersmith. London: Virago. 